\title{
Pakistan Strives to be Nuclear Power: Changed Security Environment in South Asia*
}

\author{
Prof. Dr. Razia Musarrat \\ Chairperson, Department of Political Science \\ The Islamia University of Bahawalpur \\ Bahawalpur, Pakistan
}

doi:10.5296/ jpag.v3i4.7843 URL: http://dx.doi.org/10.5296/ jpag.v3i4.7843

\begin{abstract}
Pakistan and India have remained arch rivals since their inception in 1947 fought three major wars with issue of Kashmir as their main bone of contention. Due to its size and population India always had an edge on Pakistan. Pakistan only measure for its territorial integrity was to have a strong deterrence which it achieved in the form of its nuclear weapons. India left Pakistan with no choice. Analytical technique is used while conducting this research for proving that nuclear deterrence was the only way for putting a leash on Indian aggression and constant threat.
\end{abstract}

Keywords: Empowerment, regime, harassment, discrimination, reforms

* Updated and revised 


\section{Introduction}

The footing on which Pakistan started its nuclear program is comparatively different as compared to India. Pakistani leadership demonstrated slight interest in understanding the importance of the atom whereas Indian realized the need and urgency of modern science in boosting Indian development especially during the post-independence era. Initially Pakistan's leadership stayed tied up with the considerable problems of the quest of national consolidation and maintaining domestic order in newly freed state. However during the tenure of Eisenhower, his government in December 1953 lunched its program of 'Atoms for Peace'. This was the time when Pakistani leadership woke up and pursued for the development of a small scale nuclear research programme. Then Pakistani government in October 1954 expressed an ample interest in the development of nuclear energy. Finally after two years under the headship of a Cambridge-trained physicist Dr Nazir Ahmed, Pakistan Atomic Energy Commission (PAEC) was formed. Whereas the pursuit of a nuclear device came much later. (Ahmad, 1999) In the aftermath of the humiliating defeat at India hands in 1971, President Zulfiqar Ali Bhutto met with a group of Pakistani scientists in Multan to press for the development of a nuclear bomb. (Mubarakmand, 2008)

Bhutto undoubtedly calculated forehand that Pakistan would be on greater risk due to the size and conventional superiority of India in case of any future conflict, nuclear weapons would the best option for countering any kind of future Indian intervention in Pakistan.

In short Pakistan started its efforts for acquiring its security through getting hold of a nuclear weapon proficiency in the wake of 1970s after the separation of Bangladesh in 1971.

While keeping in mind states security issues customarily, states have two possible means of ensuring their security in the chaotic international environment firstly by attaining any form of self-sufficiency and secondly through alliance. So after the Indo Pak war despite of the fact that Pakistani economy was suffering badly, Pakistan started its nuclear program even though Pakistan's economic stagnation was not allowing Pakistan to make this decision for utilizing considerable amount of resources on this project but due to the backstabbing of one of its major and supposedly trust worthy ally USA, Pakistan was left with no other choice except for achieving the status of nuclear power. Then just right after Bhutto's decision to pursue the development of nuclear weapons, Indian did their first nuclear test. Now it became mandatory for Pakistan to full fill its decision. In October 1974, five months later, Pakistan made a deal with France for a series of nuclear power plants especially designed to produce fuel through reprocessing plutonium. (Waltz, 1979)

Bhutto brought back Dr Abdul Qadir Khanto Pakistan in late 1975. He was an extremely able Pakistani metallurgist, while working at a Dutch consortium, during his stint with URENCO he gained significant knowledge regarding centrifuge enrichment process. Bhutto made him in charge of a secret programme to manufacture nuclear weapons. It is believed that Dr Abdul Qadir Khan further during the latter part of the decade, made a series of secret purchases of technological components for developing a small pilot enrichment plant. Finally, at Kahuta, near Islamabad a larger installation was developed. (Niazi, 2000) 
But then the Jimmy Care administration sitting in Washington Pakistan's started paying attention to Pakistan secret nuclear activities especially after the sale of nuclear reactor by French to Pakistan. The US Congress and the administration therefore push forward the Symington and Glen- Amendments to the Foreign Assistance Act. The Symington Amendment successfully forbade the United States will not be providing foreign assistance to countries that will not accept full scope International Atomic Energy Agency (IAEA) safeguards for importing uranium enrichment technologies. The main purpose of Glenn Amendment was to limitize the sales of reprocessing technology or the receipt of uranium enrichment plants. This amendment also successfully restricted the assistance for countries that imported plutonium-reprocessing technologies without the appropriate IAEA safeguards. At the same time, the Carter administration utilized extensive diplomatic pressure on the French government for ending the proposed transfer of reactor technology to Pakistan. And like always the United States stood successful in doing that.

But Pakistan did not backed out from its commitment of obtaining nuclear weapons. As a matter of fact after the overthrow of Zulfiqar Ali Bhutto by military dictator General Muhammad Zia-ul-Haqin a military coup in July 1977, he followed the nuclear programme even more rigorously. Although on official level Zia kept denying that Pakistan was making any efforts to acquire or manufacture nuclear weapons but he kept supporting it. (Sublette, 2002)

Than during the Soviet invasion of Afghanistan in December 1979 USAs rigorous efforts for preventing Pakistan from obtaining nuclear weapons reduced as they needed Pakistan's help for disintegrating Soviet Union. The requirements of defeating the Soviets on Afghan grounds compelled them to put the nuclear nonproliferation issue on the side for time being. Under the Ronald Reagan administration this policy was further highlighted by getting both the Symington and Glenn Amendments renounced so that Pakistan could channel US aid to the Afghan resistance. (Congress, 1977) Pakistan also became the recipient of significant US military assistance during this period. (Horn, 1989) Meanwhile India for maintaining its conventional superiority over Pakistan also used its relationship with the former Soviet Union for building up its own nuclear weapons Pakistan.

In USA though, key individuals from Congress remained busy for somehow stopping Pakistan from getting nuclear weapons. In 1985, the US Congress passed an amendment, which striped American assistance to countries seeking to illegally import nuclear supplies for use in nuclear weapons; this was called the Solarz Amendment. Regardless of the Reagan administration's effective edesertion of the non-proliferation agenda consequently, the U.S executive branch produced an agreement with Congress in the form of the Pressler Amendment for maintaining the American role in Pakistan. This amendment made it obligatory that the president of the United States must certify that 'Pakistan did not possess a nuclear explosive device' so that Pakistan becomes qualified for American assistance. Contrasting to the earlier amendments, the Pressler Amendment did not have any abandonment provisions. (Mitchell Reiss, 1995) 
Reagan and George.H.W. Bush senior administrations during the Afghan war certified to Congress that Pakistan was observing and following Pressler standard. Finally in 1990 at the end of Afghan war and when United States did not needed Pakistan help anymore Bush seniors administration ironically failed to somehow overrule the Pressler standards. Consequently, all US assistance was suspended for Pakistan.

Even though the final restrictions were tough for Pakistan but the Afghan war and the other associations had already provided with a momentous break to the programme. During this period, Pakistan made substantial gains and successfully obtained fully developed nuclear weapons according to the international standards. (Benen, 2008)

The Indian nuclear tests of May 1998 lastly compelled Pakistan for taking a decision to conduct nuclear tests. On the advice of the professional military men, Prime Minister Muhammad Nawaz Sharif, felt obligated to carry out six nuclear tests to validate that it could match India's nuclear powers. Pakistan carried out five tests on 28 May, and one more two days later. Pakistan saw India's tests as a support in its pursuit for regional supremacy and part of it as a attempt for great-power status. In short several of its reasons for going for nuclear weapons besides security were similar to India's. Pakistan has always been aware of India's superior military strength, greater wealth, population based advantage and its own vulnerability to conventional attack due to its serious lack of strategic depth.

Throughout the history since Pakistan's inception its main attention in its relations with India has been Kashmir (the 'unfinished business of partition).Even with some of the Indian allegations that Pakistan's interest in this area was never regular, and was revitalized only in 1990s for opportunistic reasons. Pakistani foreign policy been dominated by this since independence. The Shimla Agreement of 1972 clearly stated that through bilateral negotiation differences between India and Pakistan should be resolved but with coming years settlements between both hostile states demonstrated gradually decreases. Especially, a secret agreement, apparently drafted during the Shimla Agreement, according to which the Line of Control would become an international border also showed no improvement. (Dixit, 1995) In an attempt to internationalize this issue since this would have left the Kashmir Valley in Indian hands. Pakistan tried its level best to concentrate its attention on UN resolutions of the 1940s calling for a plebiscite in Kashmir. (Mustafa, 1972) But with each passing moment the condition has been intensified in Kashmir by Indian security forces constant human-rights abuse. Situation in Kashmir became quite complex India kept on interfering in Kashmiri elections while Pakistan provided military and political backing to militants Valley from the Pakistan side of the Line of Control in Kashmir. So throughout the 1990s both states remained on confrontation mode in the Kashmir Valley and in Siachen.

Kashmir issue nevertheless was the most momentous hitch faced by Pakistani government during the Indian nuclear tests. The threat was more of domestic instead of external.

In February 1997 elections Nawaz Sharif's Pakistan Muslim League (PML) won a huge mandate. After becoming Prime Minister, he set forth on eliminating the constitutional constraints on his power. Sharif attained more powers than any other elected leader after he came into power he on having disputes with Chief Justice Sajjad Ali Shah, Chief of Army 
Staff General Jehangir Karamt and President Farooq Leghari were forced to the resign or replaced.Civil order in the country was not restored. Domestic issues were involving the Shia sectarian violence in the Punjab and MohajirQaumi Movement (MQM) in Karachi. In Afghanistan Taliban access became embarrassment for the government, as they were being supported by Pakistan. In North-Wost Frontier Province religious extremism was increasing. And above allstate was suffering from chronic financial shortfalls. Foreign debtby the mid of 1998 was around some \$ 30 billion, inflation had risen to 12\%,GDP growth had fallen to 3\%, Foreign-currency reserves were less than $\$ 1$ billion (about five weeks' worth of imports. Despite Sharif's domestic political position was their governability seemed in doubt. (Rizvi, 1999)

So in the days to come when Pakistan was deciding to go for nuclear tests Sharif was under huge pressure due to the external confrontation and internal crises. Even though it remains completely vague that when this decision was taken and green signal was shown for these tests but the postponement for two weeks allowed enough time to Nawaz Sharif o mentally make up his mind and show his side of story to the world, but on other hand Indian leadership was relaxed and did not bother about the international concerns. But even if we keep India in the place of Pakistan in this situation it would also have surprised the rest of the world along with Pakistan, and most important of this entire gap was required to give some more time for the final preparations to conductors of these tests.

\section{The Foundation for Deterrence in South Asia: Pakistan's View}

Comprehensive examination of Pakistan's nuclear deterrence is not rare. Majority of the writer's opinion publicly available on this issue occasionally try to look beyond the statement that Indian hostility is being deterred by Pakistan's nuclear potential. Lately, some observations have been surfaced for addressing the issue of nuclear deterrence in reasonably more elaborately. One of the main reasons which have played its due part is reluctance of numerous important Pakistani officials. They avoid discussing this topic and as a result it has gone in the back drop. So this part will provide us an over view of this current situation and its reelection on national and international level along with an evaluation of Pakistan's nuclear deterrence from the Pakistani viewpoint.

A variability of supposed threats from India has stimulated Pakistan to search for a practical deterrent. Bolder use of conventional forces, chemical or biological weapons and guerrilla warfare all have been considered as potential candidates in this regard and have been found missing. (Beg, 1991) According to an officer from armed forces that traditional deterrence inclines to develop instability quickly with the prospect of triumph but this is no matter what but quite insignificant. (Anwari, 1998)

Therefore, among the Pakistani defense specialists a widespread agreement is present that it is the country's nuclear capability that is providing the main foundation for the states strategic deterrence against India. And this notion is completely endorsed with a wider public support for nuclear ordnances in Pakistan. Even though a different range of opinions have existed while focusing on the advantages and disadvantage of nuclear deterrence and specially keeping in mind the requirements and conditions for maintaining it, but none of 
them have dared to deprive of Pakistan of its achieved status, which was officially unrecognized, nuclear deterrence.

India's so-called nuclear weapons manufacturing capability and delivery systems are widely cited by Pakistan critics as their only justification against Pakistan's nuclear program. (Hoyt, 2006)According to the common belief this comparative disparity in traditional forces among Indopak has also been termed as the only reason behind this mad race of nuclear program. It is an open truth that Pakistan's present conventional armed forces are no match for their Indian adversaries, in both number as well as weaponry. No amount of piling up of sophisticated weaponry either through cash purchases of foreign assistance can bridge the gap in this sphere. It must, therefore hold a proper deterrent which would make India think ten times before going on board on a military escapade against Pakistan. Such a deterrent, to be reliable, must be asuitable mix of the nuclear and conventional forces. (Cheema, 2010)

Deriving from Western concepts, Pakistani analyses, the great equalizers have been given the label to the Pakistani nuclear weapons for counter weighing India's predictable supremacy and making real deterrence within means for Pakistan. Other spectators note that while Pakistan cannot achieve nuclear parity with India, a limited nuclear deterrent capability is better than none and does not suffer the same instabilities as an imbalance in conventional military power. (Cheema, 2010)In recent years nuclear exponents throughout the Pakistani exclusive structure have taken the argument further, asserting that Pakistan's nuclear capability is a proven deterrent to Indian aggression.

Shortly after,Ghulam Ishaq Khan resigned in 1993, a longtime nuclear advocate, claimed that India was deterred thrice from attacking Pakistan on three occasions during the past years due to the existence of Pakistan's nuclear program. (Khan L. C., 1999) First attempt was made according to Khan that Indira Gandhi, Indian Prime Minister in 1984 had proposed to attack Pakistan, butas India feared Pakistan's nuclear capability these plans could not be implemented and alsojust before the launch date she was killed by his personal security guard. Second attempt during 1986-87 and final in 1989-90 due to the Indian interactive arm mobilizations (initiated by the Kashmir uprising and India's Brasstacks exercise respectively) almost raised India Pakistan tensions near-war levels. According to the views of Khan and Mushahid Hussain advisers to Prime Minister Nawaz Sharif, that this nuclear factor was the only causedue to which such a direct eye to eye clash between the both states was averted and also did not transform into some big military encounter. (Hussain, 1992) General Mirza Aslam Beg provides a military approval of this view, according to him when these weapons are possessed by two blocks or two states due to the threat of mutual use neither of them use these weapons. this shows that how highly effective it as it prevents war, it is good for keeping a check on war also as both sides are living under the threat of each other. And this notion has been clearly proved that by achieving this nuclear capability Pakistan has saved itself from any kind of hostile threat and future aggression by India which was quite inevitable if Pakistan was not a nuclear power. Now both states are in equal balance and eminent threat has been neutralized. While dismissing any kind of future nuclear war between India and Pakistan even prospect of conventional war between them seems out of the horizon now. Pakistan would have been invaded and destroyed up till now if this capability was only 
achieved by the Indians, we are only safe because we have neutralized it. Currently we are only facing this Kashmir issue otherwise direct confrontation between both states is out of the window now. (Hussain, 1992)

In South Asia before India and Pakistan did their nuclear tests political constraints have always encouraged both sides not to officially admit possession of nuclear weapons, which became adistinctivefeature of the deterrent bond between Pakistan and India but as a result this vagueness left many of the technical dimensions of deterrence, for example the weakness of Pakistan's nuclear competence to a surprise attack by India. Again this survivability issue was dismissed by former director of Pakistan's Inter Service Intelligence Agency, Lieutenant General Hameed Gul. (Lavoy, 2008)It was a wild held belief by the nuclear protagonists that Pakistan would maintain its ability to retaliate even if India started a war. So it became a deterrent for starting a war as India could not rule out Pakistani retaliation.

Ironically, uncertainty for many coming years has been seen at the core of Indo-Pak deterrence. In 1980s President Mohammad Zia-ul-Haqsaid that while keeping in mind the prospect of nuclear capabilities of Pakistan that if they are creating any sort of vagueness, that vagueness is the core of Pakistani deterrence. He further said that the nuclear programs of Pakistan and India have a lot of uncertainties, but undoubtedly they have reached a certain level in each other's eyes creating an impression of deterrence which is benefitting both states.

Again related statements were also given by General Beg. He acclaimed that the belief of people in our nuclear capabilities is proving to be as deterrence for Pakistan. This was quite helpful for improving and elevating Pakistan status. People keep saying that we don't have nuclear capability and we keep on proclaiming that we do not possess them so this constant state of denial is proving to be Pakistan's deterrence.

However recently, by some Pakistani strategists nuclear uncertainty has been seen as destabilizing, including general Beg.

\section{The Stability of Deterrence under Present Circumstances}

In divergence to earlier assurance in deterrence under conditions for nuclear ambiguity, other lines of Pakistani commentary indicate a concern over the issue of credibility.

In 1980Lieutenant Colonel Masood Navid Anwar, at that point of time a dynamic duty army officer, who also happened to serve at Pakistan's General Headquarters, also drew attention to Henry Kissinger's statement that Deterrencewas equal to the capability and the use of this capability along with the enemy's willingness to use its capability and knowledge of its capability. According to Anwari, this wasthe ultimate back lash for Pakistan as he thought that the nation should be properly motivated for this kind of event for healthy response for creating the atmosphere of desirable deterrence. So on that on the psychological level nation should be ready for taking risk and make courageousness part of their national character. This will automatically give moral support to the adversaries. So this will not only help us in utilizing our destructive capabilities but also serve as the deterrence. (Anwari, 1998) 


\section{Macrothink}

Journal of Public Administration and Governance ISSN 2161-7104 2013, Vol. 3, No. 4

Since the mid-1980s a supposed need to strengthen the reliability of its nuclear deterrent may partially explain Pakistan's sincere struggles to test the limits of uncertainty. In 1987 for example, head of the uranium enrichment facility at Kahuta, DrAbdul Qadeer Khan, during Brasstacks crisis, implied at Pakistan's capability of building a nuclear bomb. (Sayer, 1988)

In 1990 former Prime Minister Benazir Bhutto gave statement to the reporters that Pakistan is capable of producing an efficient and rapid deterrent in case of emergency on the basis of sufficient information regarding nuclear technology it possess. (Blau \& Jones, 1984) After a year again, Pakistani Foreign Secretary Shahryar Khanin an interview also asserted that Pakistan was in possession of such elements which could be transformed into a nuclear device at the time of need. He also specified that this included "cores of highly enriched uranium".(Washington post,February 7, 1992)

\section{Bibliography}

Ahmad, S. (1999). Pakistan's nuclear weapons program:Turning point and nuclear choices. International Security, 178-204.

Alan Robock, O. T. (2010). Local Nuclear War, Global Suffering. New York: Scientific American.

Antony, A. (2012). India to get Admiral Gorshkov, nuclear submarine next year. New Dehli: Economic Times.

Anwari, L. C. (1998). Dettrence Hope or Reality. Pakistan Army Journal , 49.

Aron, R. (2003). Peace and War : A Theory of International Relations. New York: Transaction Publishers.

Beg, G. M. (1991). General Mirza Aslam Beg's major presentations. Defence Journal , 41.

Benen, S. (2008). Political Animal. The Washington Monthly, 30-50.

Bhutto, Z. A. (1969). The Myth of Independence. United Kingdom: Oxford University Press.

Blau, T., \& Jones, R. W. (1984). Small nuclear forces and U.S. security policy: threats and potential conflicts in the Middle East and South Asia. Michigan: Lexington Books.

Blechman, B. (2009). Russia and the United States. Washington: The Henry L. Stimson Center.

Cheema, Z. I. (2010). Indian Nuclear deterrence: Its Evolution, Development and Implications for South Asian Security. Oxford: Oxford University press.

Clark, C. S. (2007). Deception: Pakistan, the United States, and the Secret Trade in Nuclear Weapons. California: Walker \& Company.

Clarke, J. (1948). The Local Government of the United Kingdom. London: Sir Isaac Pitman \& Sons. 


\section{Macrothink}

Journal of Public Administration and Governance ISSN 2161-7104 2013, Vol. 3, No. 4

Classified congressional briefing on Pakistani clandestine Nuclear-related procurement, M-2008-00012 Doc:C17625959 (U.S Department of State 03 14, 2013).

Clinton, W. D. (1994). The Two Faces of National Interest. Louisiana State: Louisiana State University Press.

Clinton, W. (1988). National Interest: Rhetoric Leadership and Policy. United States: University Press of America.

Congress. (1977). Glenn Amendment . Columbia: Daily Digest.

Dixit, J. (1995). Anatomy of a Flawed Inheritance . New Dehli: Konark Publishers.

Gulick, E. V. (1967). Europe's Classical Balance of Power: A Case History of the Theory and Practice of One of the Great Concepts of European Statecraft. United States: Cornell University Press.

H.Khan, F. (2012). Eating Grass The Making of the Pakistani Bomb. United States: Stanford University Press.

Horn, R. E. (1989). Mapping Hypertext: The Analysis, Organization, and Display of Knowledge for the Next Generation of On-Line Text and Graphics. Virginia: Lexington Institute.

Hoyt, T. D. (2006). Military Industry and Regional Defense Policy: India, Iraq and Israel. London: Routledge.

Hussain, M. (1992). Pakistan and the Nuclear question. National Development and Security, 195-96.

Jamal, A. (2002). International Journal of bank marketing . United Kingdom: Cardiff University.

Kennan, G. F. (1951). Lectures on Foreign Policy. Chicago: University of Chicago Press.

Kerr, P. K. (1989). Pakistan's Nuclear Weapons: Proliferation and Security Issues. Philadelphia: DIANE Publishing.

Khan, L. C. (1999). Pakistan's Sovereignty: Alone or with Foreign Collaboration. Pakistan's Army Journal , 45.

Krasner, S. D. (1978). Defending the National Interest. United States: Princeton University Press.

L.Bermudez, J. (1998). The Paradox of Self-Consciousness. England: University of Cambridge.

Lavoy, F. H. (2008). "Pakistan: The Dilemma of Nuclear Deterrence," in The Long Shadow: Nuclear Weapons and Security in 21st Century Asia. Stanford: Stanford University Press.

Lippmann, W. (1925). The Phantom Public. United States: Transaction Publishers. 
Machiavelli, N. (1882). History of Florence and The Prince. London: George Bell and Sons.

Misquita, S. (2009). Defense Contractors Target Big Jump in India's Military Spending. The Wall Street Jounal , 10.

Mitchell Reiss, B. A. (1995). Why Countries Constrain Their Nuclear Capabilities. D.C Washington: Woodrow Wilson CenterPress.

Moos, T. C. (1953). The American Idea of National Interst. United States: The John Hopkin University.

Morgenthau, H. J. (1960). The Purpose of American Politics. New York: New York Publishers.

Mubarakmand, S. (2008). A science Odyssey : Pakistan's nuclear emergence. United States: Routledge.

Mustafa, Z. (1972). THE KASHMIR DISPUTE AND THE SIMLA AGREEMENT. Pakistan Horizon , 38-52.

N.Rosenau, J. (1980). The Scientific Study Of Foerign Policy. London: Frances Pinter.

Nation, U. (2009). Nuclear non-proliferation and nuclear disarmament. United Nations: UN News Center.

Nessman, R. (4 April 2012). India Nuclear Missile Test: Agni-V Missile Has Capability To Hit Chinese Cities. New Dehli: Huffington Post.

News, B. (2010). Renewed strains between Islamabad and Washington. United Kingdom: www.BBC.com.

Niazi, M. K. (2000). Aur Line Kat Gai. Lahore: Dogar Publishers.

Nigham, S. (1982). Local Government. New Dehli: S. Chand and Company.

Nye, J. S. (2002). The Paradox of American Power. United Kingdom: Oxford University Press.

Qazi, S. H. (2012). Making the Bomb: Pakistan's Nuclear Journey. California: Stanford University Press.

Rizvi, H. A. (1999). Pakistan in 1998: The politics under pressure. Asian Survey,vol.39 , 177-85.

Roskin, M. G. (1994). National Interest: From Abstraction to Strategy. Pennsylvania: Strategic Studies Institute Publications.

Roskin, M. G. (1994). National Interest: From Abstraction to Strategy. United States: New York Press.

Sayer, T. (1988). Nuclear arm control,nuclear deterrence in the post cold war period. London: Macmillam Press. 


\section{Macrothink \\ Journal of Public Administration and Governance \\ ISSN 2161-7104 \\ 2013, Vol. 3, No. 4}

Shahid, S. (2003). Taqabli-o-Taraqiati Siasat. Lahore: Urdu Digest .

Sublette, C. (2002). Are Suitcase Bombs Possible? New York: Chuckelea Publishing.

Taseer, S. (1979). Bhutto A Political Biography. Lahore: Sani Hussain Panhwar.

Tocqueville, A. d. (1961). Democracy in America, trans. Henry Reeve. New York: Cornell University Press.

Turner, M. (1997). Governance, administration and development: Making the state work. Netherland: Macmillan.

W.Thompson, H. M. (1948). Politics Among Nations. New York: McGraw - Hill.

Waltz, K. N. (1979). Theory of international politics. Michigan: Addison-Wesley Pub.

Weissman, S. (1981). The Islamic Bomb. New York: Times Books. 